\title{
Comparative Analysis of Applications and Disbursements of Loans to Beneficiaries by Bank of Agriculture in Anambra State, Nigeria
}

\author{
Isibor Annunciata Chinwe ${ }^{1, *}$, Nkamigbo Darlington Chineze ${ }^{2}$ \\ ${ }^{1}$ Department of Agricultural Economics \& Extension, Faculty of Agriculture, Nnamdi Azikiwe University, Awka, Anambra, Nigeria \\ ${ }^{2}$ Department of Agricultural Technology, School of Agriculture and Related Discipline, Anambra State Polytechnic, Mgbakwu, Nigeria
}

Email address:

chinweann@yahoo.com (I. A. Chinwe), chinezenkamigbo@yahoo.com (N. D. Chineze)

${ }^{*}$ Corresponding author

\section{To cite this article:}

Isibor Annunciata Chinwe, Nkamigbo Darlington Chineze. Comparative Analysis of Applications and Disbursements of Loans to Beneficiaries by Bank of Agriculture in Anambra State, Nigeria. International Journal of Agricultural Economics.

Vol. 4, No. 5, 2019, pp. 195-200. doi: 10.11648/j.ijae.20190405.11

Received: May 21, 2019; Accepted: June 29, 2019; Published: August 5, 2019

\begin{abstract}
The study investigated the comparative analysis of loan applications and disbursements to large and small scale farmer beneficiaries of Bank of Agriculture from 2010-2016 in Anambra State, Nigeria. The specific objectives were to ascertain the socio-economic characteristics of the large and small scale farmer beneficiaries, to estimate the total amounts of applications and disbursements to large and small farmer beneficiaries of BOA loans and constraints militating against loan administration by BOA staff. A multistage sampling procedure involving purposive and random sampling methods were used to select 256 respondents for the study. Data were collected from both primary and secondary sources. Primary data were collected using two sets of questionnaire; one for the farmers and the other for the bank officials while secondary data were sourced from loan transaction records in the headquarters and branch offices of BOA in the State. Collected data were analyzed using descriptive statistics technique. Findings indicated that the large scale farmers were more advanced in age, more educated, had higher years of farming experience, number of persons in the household and number of males among them than the small scale farmers, who, however, were better at repayment. Majority $(60.00 \%)$ of applications and $60.33 \%$ of disbursements to the large scale farmers were for poultry and fish production while the small scale farmers' most $(53.28 \%)$ applications and disbursements (53.26\%) were for the production of crops. The most serious constraints to loan administration by the bank staff were low repayment rate, inadequate fund for lending, insufficient staff for credit administration, inadequate collateral provision and loan diversion by beneficiaries. The provision of more funds, more skilled staff, and adequate logistics to the BOA by government, timely disbursed of approved amount, minimization of bureaucratic procedure involved in the administration of the facilities by the BOA and formation of more cooperative groups by the beneficiaries were recommended.
\end{abstract}

Keywords: Comparative, Loan, Large and Small Scale, Beneficiaries

\section{Introduction}

Agriculture plays vital roles in the economies of all countries of the world especially developing economies like Nigeria [1]. Agriculture has traditionally been acknowledged as the mainstay of Nigerian economy. It provides employment and income to about $70 \%$ of the population, food for the people, raw materials for industries and foreign exchange for the country [2]. According to [3], the sector accounted for well over $80 \%$ of the export earnings and about
$50 \%$ of government revenue in the $1960 \mathrm{~s}$ prior to the discovery of crude oil. Unfortunately, over the years the sector has witnessed tremendous decline in its contribution to the national output. Currently, agriculture is contributing about $42 \%$ of the gross domestic product (GDP) of Nigeria (Central Bank of Nigeria [4]. One of the reasons for decline in the contributions of agriculture to the economy of Nigeria is lack of a stable National Credit policy and paucity of credit institutions which can assist farmers [5-6].

Credit is a crucial factor in the development of the rural 
sector. One of the major inputs identified over the years in the development of the Nigerian agricultural sector has been the agricultural credit [7]. Access to credit facilities of these poor rural people has the potential of making the difference between eradicating poverty and securing life economically as well as enhancing agricultural productivity [8]. One of the problems confronting farmers and consequently agricultural productivity and growth in Nigeria is inadequate capital despite the glaring contributions of agricultural sector in the overall economic development of the country [9]. For instance, agricultural credit in Nigeria as a percentage of banks' total credit was $1.4 \%$ in 2008 and has averaged $2.5 \%$ over the last few years. Agricultural credit is closely related to providing needed resources, which most farmers cannot source from their personal savings. In this regard, the provision of credit has to be made a vital way of promoting agricultural development in Nigeria.

The provision of this input is very important because credit or loanable fund (capital) is viewed as more than just another resource such as labour, land, equipment and raw materials. It determines access to all of the resources on which farmers depend. Some studies blamed shortage of agricultural credit on commercial banks' reluctance to offer credit for farming enterprise in Nigeria $(10 ; 11)$. Banks refers to farmers (especially small-scale farmers) as "bad risks and unbankable" and therefore adopt risk averse attitude towards them. For instance, [12] observed that the agricultural sector which accounted for the largest single portion (about 42\%) of national output (GDP) was the least favoured by commercial banks in terms of loans and advances among all economic sectors. From 2006 to 2008 the average annual flow of bank credit was mere $2.27 \%$ [13], and only about $18 \%$ of farm households had access to financial services in Nigeria [14]. The Central Bank publication [also reported that only $2.5 \%$ of total commercial bank loans and advances were directed at agriculture (15). A direct consequence of this situation is the general poverty especially among rural people. Ironically, in most of the developing countries such as Nigeria, the economic development is extricable trapped in a vicious cycle of insufficient investment and resource input, low productivity and low level savings resulting in low level output.

\section{Materials and Methods}

The study area was Anambra State, Nigeria, it consists of twenty-one (21) Local Government Areas (LGA) and four agricultural zones. The State is located between latitudes $6^{0}$ $45^{1}$ and $5^{0} 44^{1} \mathrm{~N}$ and longitudes $6^{0} 36^{1}$ and $7^{0} 29^{1} \mathrm{E}$. It has a population of $4,182,032$ [16]. Agriculture is the predominant occupation in the rural areas engaging more than $70 \%$ of the rural population.

Both the large and small scale farmers in the area have benefitted from credit facilities of the Bank of Agriculture (BOA) for the various crops, livestock and fisheries production activities. This was possible because of the existence of the bank's branch offices in the three Senatorial zones of the State, as well as ease of accessibility to credit facilities of the bank by the farmers from the headquarters strategically located at the center of Awka, the capital city of Anambra State.

\subsection{Population and Sampling Procedure}

The study population comprised all farmers who have benefited from the BOA credit facilities in Anambra State of Nigeria and staff of the BOA branch offices in Awka. Nteje, Oko and Ukpo. A multistage sampling procedure involving purposive and random sampling methods were used to select four agricultural zones, 12 LGAs, 240 (120 large scale and 120 small scale) farmer-beneficiaries of BOA credit facilities and 16 BOA staff for the study.

Stage 1: The four Agricultural zones were purposively selected because of the existence of an office of the BOA in the zones. At stage II, three LGAs were randomly selected from each of the selected agricultural zones to arrive at 12 LGAs. Stage III witnessed the random selection of five large scale and five small scale farmer-beneficiaries of the bank's loans from each of the 12 selected LGAs to arrive at a total of 240 respondents (120 large scale farmers and 120 small scale farmers). In addition, 16 of the Bank of Agriculture staff were randomly selected for information on loan administration by $\mathrm{BOA}$ to arrive at a grand total of 256 respondents.

\subsection{Method of Data Collection and Analysis}

Data were collected from both primary and secondary sources. Primary data were collected using two sets of questionnaire, one for the farmers and the other for the bank officials. The questionnaires were designed to collect information on the farmers' socio-economic characteristics, loan applications and disbursements and constraints. Secondary data were sourced from the headquarters and branch offices of the BOA in the State. Data collected were achieved by the use of descriptive statistical tools such as means, frequency counts and percentages.

\subsection{Measurement of Variables}

The dependent and independent variables were measured as follows:

Age: This was measured as actual ages of the farmer in years.

Gender: Dummy variables were used to represent the farmer's sex as 1 for male and 2 for female.

Educational Attainment: Number of years of formal education obtained by each farmer.

Marital Status: This was measured as dummies (dummy: married $=1$; otherwise $=2$ ).

Household Size: Number of persons living together in a household.

Farming experience: This was estimated as the number of years the farmer has been in the business.

Farm Size: This is a measure of the area of land being utilized by the farmer 
Farm Income: This was measured as annual farm income of the respondent farmer.

Total income of farmer: This was measured as total annual income of the respondent farmer from farming and nonfarming activities.

Production Cost: This showed the total amount of money the farmer spent during the last production period.

Amount of loan disbursed to farmer: This was the total amount of money the bank actually gave to the farmer for farming activities.

Interest rate: This was measured as the prevailing interest rate for the bank's facilities as at the year of study.

Large scale farmer: This represents the farmer who obtained a loan of $\$ 500,000$ or above from the bank.

Small scale farmer: Reflects the farmer who obtained between $\$ 50,000$ and $\$ 250,000$ from the bank. Constraints to loan repayment/default and loan administration: A 4-point Likert type scale was used to collect data on constraints to loan repayment/default and loan administration.

\section{Result}

\subsection{Socio-Economic Characteristics of the Large and Small Scale Farmer-Beneficiaries of Bank of Agriculture (BOA) Loans}

Socio-economic characteristics in Table 1 indicates that majority $(81.7 \%$ and $85.8 \%)$ of the large and small scale farmers respectively fell under the active age range of 20-50 years with average age of 42.5 and 39.7 respectively. The study [17] confirmed that young people possesses the strength required for active participation and increased production for agricultural enterprises. Education is a veritable tool in accessing and management of agricultural credit and the higher the educational level of a farmer, the better the chances of accessing and repaying formal and quasi-formal credits, and the lower the rate of default [18]. Distribution of respondent according to educational level shows that the large scale farmers were more educated than the small scale farmer since many $(45.8 \%)$ and few $(20.0 \%)$ of the large and small scale farmers respectively obtained tertiary educational qualification.

The result revealed that large scale farmers $(46.7 \%)$ were more experienced than the small scale farmers $(29.2 \%)$ in the agricultural ventures sponsored by the BOA with the average years of 20.8 years. The study [1] stressed the positive influence of high years of farming experience in credit access and repayment of the male and female cooperative farmerbeneficiaries of BOA micro loans in Awka agricultural zone of Anambra State, Nigeria.

In the rural communities where most farming activities take place, marital status is considered an important factor in the determination of family labour availability, and confers responsibility on individuals [19]. The distribution of respondents by marital status shows that majority $(62.5 \%$ of the large scale and $54.2 \%$ of the small scale) farmers were married, implying that most of the respondents are responsible in line with the deductions of the study [19]. The result reveals that the average household size was 7 persons for the large scale farmers and 6 persons for the small scale farmers.

Distribution of respondents according to gender showed that majority of the large (79.2\%) and small scale (63.3\%) farmer-beneficiaries of the BOA loans were males while the rest $(28.8 \%)$ and $(36.7 \%)$ farmers were females. This implied that the female farmers were more skeptical in their approach to accessing credit facilities for the agricultural ventures. The study [20] reported than more males than female farmerbeneficiaries of microfinance banks' loans in Idemili LGA of Anambra State, Nigeria were able to access the credit facilities.

Result of data analysis on repayment rates indicates that for the large scale farmers; full repayment was $10.0 \%$ of the respondents, half repayment $20.8 \%$, less than half $54.2 \%$ and zero repayment $15.0 \%$. For the small scale farmers; full repayment was $25.0 \%$, half $29.2 \%$, less than half $25.0 \%$ and zero repayment $20.8 \%$. This implies that the small scale farmers were better than the large scale farmers having recorded full repayment rate of $25.0 \%$ contrary to the full repayment rate of $10.0 \%$ recorded for the large scale farmers. It could equally mean that there were more diversions of the facilities among the large scale farmers, probably because the large scale farmers, with males constituting majority, utilized the facilities for social responsibilities outside that for which the loan was disbursed. Also, the smallholder female beneficiaries have better repayment rates for micro credit loans (1).

\subsubsection{Applications by the Large and Small Scale Farmer-beneficiaries of $\mathrm{BOA}$ Credit Facilities}

The distribution of applications made by the large and small scale farmer-beneficiaries of the BOA loans according to the enterprises sponsored with the money is shown in Table 2. The result indicated that out of the total amount of credit $(\$ 3,264,905,000)$ applied for by pooled large and small scale farmers for the various enterprises, about $\$ 1,784,645,000$ constituting majority $(54.66 \%)$ of the total amount was meant for poultry and fisheries production while the remaining amount, $\$ 1,480,260,000$ or $45.34 \%$ was made for the production of different crops. The large scale farmers made more applications $(60.00 \%)$ for poultry and fish production than the $40.00 \%$ of the applications directed to crops' production. On the contrary, the small scale farmers were more interested in the production of crops, towards which they channeled majority $(53.28 \%)$ of their applications than the rest $46.72 \%$ meant for poultry $(33.59 \%)$, piggery $(3.26 \%)$, and fisheries $(9.87 \%)$.

\subsubsection{Disbursements to the Large and Small Scale Farmer-beneficiaries of $\mathrm{BOA}$ Credit Facilities}

Similar to the pattern of distribution of applications Table 3 , the large scale farmers obtained more loan $\$ 416,375,000$ constituting $60.33 \%$ of the total disbursed amount of $\$ 690$, 200,000 for crops, livestock and fisheries production for livestock and fisheries production, than the $\$ 77,658,000$ or 
$46.74 \%$ of the total amount meant for the same purpose disbursed to the small scale farmers (Table 3). The small scale farmers received majority $(53.26 \%)$ of their disbursements for the production of crops than the $49.67 \%$ obtained from the bank for similar ventures by the large scale farmers. For the pooled large and small scale farmers, majority $(56.87 \%)$ of the bank's disbursements went to livestock and fisheries production than the rest $43.13 \%$ of the disbursements that were meant for crops' production. The reason for this pattern of disbursement by the bank might be due to the capital intensive nature of livestock and fisheries enterprises than the cropping enterprises that require smaller start-up capital. Some studies confirmed the capital intensive nature of fish and poultry enterprises $(18,21)$.

\subsection{Constraints to Loan Administration by the BOA Staff}

The problems militating against loan administration by the BOA staff are shown in Table 4. According to the result, low repayment rate with a mean score of 3.88 was the most serious problem, followed by inadequate fund for lending $(\mathrm{M}=3.24)$, insufficient staff for credit administration $(\mathrm{M}=2.76)$, inadequate collateral provision $(\mathrm{M}=2.51)$, loan diversion by beneficiaries $(\mathrm{M}=2.50)$, high administrative cost $(\mathrm{M}=1.85)$, supply of false data by the farmers $(\mathrm{M}=1.80)$, and the least, bureaucratic/logistic challenges $(M=1.56)$. Nonrepayment of loans by farmers, high default rate, inadequate monitoring and evaluation, illiteracy of farmers and lack of farmers' awareness about bank products (innovation) were among the greatest constraints that hinder loan administration by bank officials (22). Also stated that financial lending institutions in Nigeria often shy away from the high cost of administering such loans and the perceived high defaults rates among farmers (23).

\subsection{Differences Between Loan Applications and Disbursements by the Large and Small Scale Farmers}

The result of test of hypothesis of no significant differences between applications made by the large and small scale farmers, disbursements made by the BOA to the large and small scale farmers is shown in Table 5. It could be seen from the result that there were significant differences between applications made by the large and small scale farmers at $1 \%$ probability level, between disbursements to the large and small scale farmers at $1 \%$ alpha level. In each case the large scale farmers were favoured. This implies higher the amount of credit applied for by the bank's customer, higher the expected disbursement, repayment and most likely default.

\section{Summary}

Findings on socio-economic characteristics of the respondents showed that average age of the large scale farmers was 42.5 years while the small scale farmers averaged 39.7 years; the large scale farmers were more educated than the small scale farmer since many $(45.8 \%)$ and few $(20.0 \%)$ of the large and small scale farmers respectively obtained tertiary educational qualification; average years of farming experience of the large scale farmers (20.8 years) was also higher than that of the small scale farmers $(12.7$ years); majority $(62.5 \%$ of the large scale and $54.2 \%$ of the small scale) farmers were married; average household size was 7 persons for the large scale farmers and 6 persons for the small scale farmers; more males $(79.2 \%)$ were among the large scale farmers than the $63.3 \%$ male farmers among the small scale farmers; and the small scale farmers were better at repayment having recorded full repayment rate of $25.0 \%$ contrary to the full repayment rate of $10.0 \%$ recorded for the large scale farmers.

\section{Conclusion}

On applications, the large scale farmers made more applications $(60.00 \%)$ for poultry and fish production than the $40.00 \%$ of the applications directed to crops' production. On the contrary, the small scale farmers were more interested in the production of crops, towards which they channeled majority (53.28\%) of their applications than the rest $46.72 \%$ meant for poultry $(33.59 \%)$, piggery $(3.26 \%)$, and fisheries $(9.87 \%)$. On disbursements, the large scale farmers obtained more loan, $\$ 416,375,000$ constituting $60.33 \%$ of the total disbursed amount of $\$ 690,200,000$ for crops, livestock and fisheries production for livestock and fisheries production, than the $\$ 77,658,000$ or $46.74 \%$ of the total amount meant for the same purpose disbursed to the small scale farmers. The small scale farmers received majority (53.26\%) of their disbursements for the production of crops than the $49.67 \%$ obtained from the bank for similar ventures by the large scale farmers.

Table 1. Socio-economic factors of farmer-beneficiaries of the BOA loans.

\begin{tabular}{|c|c|c|c|c|c|c|c|}
\hline \multirow{2}{*}{ Variable } & \multirow{2}{*}{ Large Scale Farmers } & \multicolumn{6}{|c|}{ Small Scale Farmers } \\
\hline & & Freq. & $\%$ & Mean & Freq. & $\%$ & Mean \\
\hline \multicolumn{8}{|l|}{ Age } \\
\hline $20-30$ & & 36 & 30.0 & - & 25 & 28.8 & - \\
\hline $31-40$ & & 38 & 31.7 & - & 46 & 38.3 & 39.7 years \\
\hline $41-50$ & & 24 & 20.0 & 42.5 years & 32 & 26.7 & - \\
\hline Above 50 & & 22 & 18.3 & - & 17 & 14.2 & - \\
\hline \multicolumn{8}{|l|}{ Educational Level } \\
\hline No formal education & & 10 & 8.3 & - & 31 & 25.8 & - \\
\hline Primary & & 20 & 16.7 & - & 50 & 41.7 & 6.8 years \\
\hline Post primary & & 35 & 29.2 & 12.6 years & 15 & 12.5 & - \\
\hline
\end{tabular}




\begin{tabular}{|c|c|c|c|c|c|c|c|}
\hline \multirow{2}{*}{ Variable } & \multirow{2}{*}{ Large Scale Farmers } & \multicolumn{6}{|c|}{ Small Scale Farmers } \\
\hline & & Freq. & $\%$ & Mean & Freq. & $\%$ & Mean \\
\hline Tertiary & & 55 & 45.8 & - & 24 & 20.0 & - \\
\hline \multicolumn{8}{|l|}{ Farming Experience } \\
\hline Less than 10 & & 5 & 4.2 & - & 20 & 16.7 & \\
\hline $10-20$ & & 56 & 46.7 & - & 35 & 29.2 & 12.7 years \\
\hline $21-30$ & & 29 & 24.2 & 20.8 years & 50 & 41.7 & - \\
\hline Above 30 & & 30 & 25.0 & - & 15 & 12.1 & \\
\hline \multicolumn{8}{|l|}{ Marital Status } \\
\hline Single & & 25 & 28.8 & - & 41 & 34.2 & - \\
\hline Married & & 75 & 62.5 & - & 65 & 54.2 & - \\
\hline Divorced & & 2 & 1.7 & - & 4 & 3.3 & - \\
\hline Widowed & & 18 & 15.0 & - & 10 & 8.3 & - \\
\hline \multicolumn{8}{|l|}{ Household Size } \\
\hline $1-5$ & & 35 & 29.2 & - & 65 & 54.2 & - \\
\hline $6-10$ & & 72 & 60.0 & 7 persons & 50 & 41.7 & 6 persons \\
\hline Above 10 & & 13 & 10.8 & - & 5 & 4.2 & - \\
\hline \multicolumn{8}{|l|}{ Gender } \\
\hline Male & & 95 & 79.2 & - & 76 & 63.3 & - \\
\hline Female & & 26 & 28.8 & - & 44 & 36.7 & - \\
\hline \multicolumn{8}{|l|}{ Repayment } \\
\hline Full & & 12 & 10.0 & - & 30 & 25.0 & - \\
\hline Half & & 25 & 20.8 & - & 35 & 29.2 & - \\
\hline Less than half & & 65 & 54.2 & - & 30 & 25.0 & - \\
\hline Zero & & 18 & 15.0 & - & 25 & 20.8 & - \\
\hline
\end{tabular}

Source: Field survey, 2017. Note: Freq. = Frequency.

Table 2. Applications by Large and Small Scale Farmer-beneficiaries of BOA Loans (2010-2016).

\begin{tabular}{lllllll}
\hline \multirow{2}{*}{ Enterprise } & \multicolumn{2}{l}{ Large Scale Farmers } & \multicolumn{2}{l}{ Small Scale Farmers } & \multicolumn{2}{l}{ Large \& Small Scale } \\
\cline { 2 - 7 } & Amount (N) & \% of Total & Amount (N) & \% of Total & Amount (N) & \% of T \\
\hline Crops & $780,750,000$ & 40.00 & $699,510,000$ & 53.28 & $1,480,260,000$ & 45.34 \\
Livestock & & & & & & - \\
Piggery & - & - & $42,759,000$ & 3.26 & - & 54.66 \\
Poultry \& Fish & $1,171,250,000$ & 60.00 & $441,000,000$ & 33.59 & $1,784,645,000$ & \\
Fisheries & & & $129,600,000$ & 9.87 & & \\
Total & $1,952,000,000$ & 100.00 & $1,312,905,000$ & 100.00 & $3,264,905,000$ & 100.00 \\
\hline
\end{tabular}

Source: Field survey, 2017. Note: $\mathrm{T}=$ Total.

Table 3. Disbursements to the Large and Small Scale Farmer-beneficiaries of BOA Loans (2010-2016).

\begin{tabular}{lllllll}
\hline \multirow{2}{*}{ Enterprise } & \multicolumn{2}{l}{ Large Scale Farmers } & \multicolumn{2}{l}{ Small Scale Farmers } & \multicolumn{2}{l}{ Large \& Small Scale } \\
\cline { 2 - 7 } & Amount (N) & \% of Total & Amount (N) & \% of Total & Amount (N) & \% of T \\
\hline Crops & $273,825,000$ & 39.67 & $88,494,000$ & 53.26 & $362,319,000$ & 43.13 \\
Livestock & & & & & & - \\
Piggery & - & - & $5,418,000$ & 3.26 & - & 56.87 \\
Poultry \& Fish & $416,375,000$ & 60.33 & $55,986,000$ & 33.59 & $477,779,000$ & \\
Fisheries & & & $16,254,000$ & 9.78 & & \\
Total & $690,200,000$ & 100.00 & $166,152,000$ & 100.00 & $3,264,905,000$ & 100.00 \\
\hline
\end{tabular}

Source: Field survey, 2017. Note: $\mathrm{T}=$ Total.

Table 4. Problems militating against loan administration by the BOA staff.

\begin{tabular}{lll}
\hline Problem & Mean Score & Rank \\
\hline Low repayment & 3.83 & $1^{\text {st }}$ \\
Inadequate fund for lending & 3.24 & $2^{\text {nd }}$ \\
Insufficient staff for credit administration & 2.76 & $3^{\text {rd }}$ \\
Inadequate collateral provision & 2.51 & $4^{\text {th }}$ \\
Loan diversion by beneficiaries & 2.50 & $5^{\text {th }}$ \\
High administration cost & 1.85 & $6^{\text {th }}$ \\
Supply of false data by the farmers & 1.80 & $7^{\text {th }}$ \\
Bureaucratic/Logistic challenges & 1.56 & $8^{\text {th }}$ \\
\hline
\end{tabular}

Source: Field survey, 2017. 
Table 5. Test of hypotheses about differences between applications, disbursements, repayments and defaults by the large and small scale farmers.

\begin{tabular}{|c|c|c|c|c|}
\hline Pairs of loan group & $\mathbf{N}$ & Mean & Differences between Means & T-ratio \\
\hline LSFA & 120 & $16,266,667$ & & \\
\hline SSFA & 120 & $10,948,875$ & $5,325,792$ & $34.57 * * *$ \\
\hline LSFD & 120 & $5,751,667$ & & \\
\hline SSFD & 120 & $1,384,600$ & $4,367,067$ & $19.49 * * *$ \\
\hline LSFR & 120 & 960,520 & & \\
\hline SSFR & 120 & 595,593 & 364,926 & $2.15^{* *}$ \\
\hline LSFD & 120 & $4,791,146$ & & \\
\hline SSFD & 120 & 789,006 & $4,002,139$ & $12.36 * * *$ \\
\hline
\end{tabular}

Source: Field survey, 2017. Notes: $\mathrm{N}=$ Number of respondents. $* * *=$ significant at $1 \%$ alpha level. $* *=$ Significant, $\mathrm{p}<0.05 . \mathrm{LSF}=\mathrm{Large}$ scale farmer. SSF $=$ Small scale farmer. $\mathrm{A}=$ Application. $\mathrm{D}=$ Disbursement. $\mathrm{R}=$ Repayment. $\mathrm{D}=$ Default.

\section{References}

[1] Chikezie, N. P., Omokore, D. F., Akpoko, J. G. \& Chikaire, J (2012). Factors influencing rural youth adoption of cassava recommended production practices in Onu-Imo Local Government Area of Imo State, Nigeria. Greener Journal Of Agricultural Science, 2 (6), 259-268.

[2] Obasi, P. C. \& Agu, S. E. (2000). Economics of small scale rice farmers under different production systems in South Eastern Nigeria. Journal of Agriculture, Business and Rural Development, 1 (2), 2-8.

[3] Lawal, A. M. \& Ette, O. A. (2006). "Analysis of agricultural production in Nigeria" African Journal for Agricultural Research, 2 (1), 20-36.

[4] Central Bank of Nigeria (2011). Monetary, Credit, Foreign Trade and Exchange Policy Guidelines for Fiscal Years 2010/2011 (Monetary policy circular No. 38).

[5] Afolabi, J. A. (2010). "Analysis of loan repayment among small scale farmers in Oyo state" Journal of Social Sciences, $22(2), 115-119$.

[6] Nwachukwu, I. N., Alamba, C. S. \& Oko-Isu, A. (2010). "Determinant of institutional credit repayment performance among farmers in Afikpo North LGA of Ebonyi State, Nigeria” AAB BIOFLUX 2 (3), 211-226.

[7] Central Bank of Nigeria (2005). Agricultural Credit guarantee scheme fund in Nigeria (ACGSF): an impact assessment. Study conducted by center for research analysis and management for the governing board of the ACGSF, Abuja.

[8] Zeller, M. \& Sharma, M. (1998). Rural financial services for poverty alleviation.

[9] Odoemenam, I. U. \& Obinne, C. O. (2010). Assessing the factors influencing the utilization of improved cereal crop production technologies by small scale farmers in Nigeria. Retrived July 10th 2016 from www.indjust.org/archive/vol. 3.issue2/innocent-17.pdf.

[10] Nwau, J. C, (2011). "Determinant of informal credit demand and supply among food crop farmers in Akwa Ibom, Nigeria, Journal of Rural and Community Development, 6 (1), 129134.

[11] Essien, U. A., \& Idiong, I. C. (2008). The determinants of the use of credit by food crop farmers in Akwa Ibom State of Nigeria. Global Journal, 6 (8), 32-39.

[12] Eboh, E. C., Nwafor, M., Chukwu, J. O. \& Amuka, J. I.
(2011). Cost-effective agriculture growth options for poverty Reduction in Nigeria: Evidence and Policy implications. African Institute for Applied Economics, Research paper 6.

[13] Central Bank of Nigeria (2009). Annual Report and Statement of Account, 80-93.

[14] Akramov, K. T. (2009). Decentralization, Agricultural services and Determinants of input use in Nigeria, International Food Policy Research Institute (IFPRI), Discussion paper 00941, Developmment strategy and governance Division, 23.

[15] Central Bank of Nigeria (2008). Statistical bulletin, Golden Jubilee Edition, Abuja, CBN Publication.

[16] National Population Commission (2006). Population Census Report National Population Commission of Nigeria, Abuja.

[17] Onyeagocha, S. U., Chidebelu, S. A. N. D., Okoriji, E. C., Ukoha, A. H., Osuji, M. N. and Korie, O. C. (2012). Determinants of Loan Repayment of Microfinance Institutions in Southeast States of Nigeria. International Journal of Social Science and Humanities, 1 (1), 12-19.

[18] Ike, P. C. \& Ugwumba, C. O. (2009). Gender access to microcredit in Delta State, Nigeria: Implication for enhanced agricatural production, International Journal of Agriculture, Economics and Extension, 1 (1), 82-86.

[19] Ebewore, S. O. (2010) Assessment of Loan Administration by a micro finance bank food and agricultural organization (2006); Rapid growth of selected Asian Countries. Lessons and Implications for agricultural and food security synthesis report. Bangkok: Regional office for Asia and the pacific.

[20] Ugwumba, C. O. A., Omojola, J. T. and Azifuaku, E. N. (2014). Credit Access and Repayment by FarmerBeneficiaries of Microfinance Banks' Loans in Idemili North LGA, Anambra State, Nigeria. Journal of Environmental Science, Computer Science \& Engineering \& Technology, 3 (4), 1733-1741.

[21] Ugwumba, C. O. A, Okoh, R. N. \& Uzoegbunam, C. O. (2011). Marketing structure of live catfish in Anambra State, Nigeria. Journal of Agriculture and Social Science. 7 (10), 25-29.

[22] Kuye O. O. (2015). "Determinants of loan default and repayment rates by cassava farmers in south-south Nigeria: A case study of Bank of Agriculture and First bank of Nigeria" European J. Agric. Forestry Research, 3(4), 48-57.

[23] Adegbite, D. A. (2009). Repayment performance of beneficiaries of Ogun State Agriculture and Multipurpose Credit Agency (OSAMCA) in Ogun State (2004-2007). American-Eurasian Journal of Sustainable Agriculture, 3 (1), 117-125. 